\title{
Is There a Predisposition towards the Use of New Technologies within the Traffic Field of Emerging Countries? The Case of the Dominican Republic
}

\author{
Francisco Alonso ${ }^{1,2, *(\mathbb{D})}$, Mireia Faus ${ }^{1}\left[\right.$, Cristina Esteban ${ }^{1,2}$ and Sergio A. Useche ${ }^{1,2}$ (D) \\ 1 DATS (Development and Advising in Traffic Safety) Research Group, INTRAS (Research Institute on Traffic \\ and Road Safety), University of Valencia, 46022 Valencia, Spain; mireia.faus@uv.es (M.F.); \\ cristina.esteban@uv.es (C.E.); sergio.useche@uv.es (S.A.U.) \\ 2 Faculty of Psychology, University of Valencia, 46010 Valencia, Spain \\ * Correspondence: francisco.alonso@uv.es
}

check for

updates

Citation: Alonso, F.; Faus, M.;

Esteban, C.; Useche, S.A. Is There a

Predisposition towards the Use of

New Technologies within the Traffic

Field of Emerging Countries? The

Case of the Dominican Republic.

Electronics 2021, 10, 1208.

https://doi.org/

10.3390/electronics10101208

Academic Editor: Alexey Vinel

Received: 19 April 2021

Accepted: 17 May 2021

Published: 19 May 2021

Publisher's Note: MDPI stays neutral with regard to jurisdictional claims in published maps and institutional affiliations.

Copyright: (c) 2021 by the authors. Licensee MDPI, Basel, Switzerland. This article is an open access article distributed under the terms and conditions of the Creative Commons Attribution (CC BY) license (https:// creativecommons.org/licenses/by/ $4.0 /)$.

\begin{abstract}
Technological devices are becoming more and more integrated in the management and control of traffic in big cities. The population perceives the benefits provided by these systems, and, therefore, citizens usually have a favorable opinion of them. However, emerging countries, which have fewer available infrastructures, could present a certain lack of trust. The objective of this work is to detect the level of knowledge and predisposition towards the use of new technologies in the transportation field of the Dominican Republic. For this study, the National Survey on Mobility was administered to a sample of Dominican citizens, proportional to the ONE census and to sex, age and province. The knowledge of ITS topics, as well as the use of mobile applications for mobility, are scarce; however, there was a significant increase that can be observed in only one year. Moreover, technology is, in general, positively assessed for what concerns the improvement of the traffic field, even though there is a lack of predisposition to provide one's personal data, which is necessary for these devices. The process of technological development in the country must be backed up by laws that protect the citizens' privacy. Thus, technologies that can improve road safety, mobility and sustainability can be implemented in the country.
\end{abstract}

Keywords: ITS systems; sustainability; road safety; mobility in traffic

\section{Introduction}

The massive development of transport systems in cities has implied an increase in the infrastructural requirements needed for their operation, in addition to the changes in the order of urban areas and transportation modes [1,2]. In this sense, in many cities some efficient mechanisms for the control of traffic and mobility have been implemented, thus avoiding traffic jams and increasing sustainability $[3,4]$.

Technology has experienced exponential growth during recent years, with devices and applications being created for the specific utility of citizens [5]. The use of electronic devices and information/communication technologies (ICTs) is currently completely integrated within the transport field in most countries, being part of the process of sustainable urbanization [6]. The comforts they offer to users range from road searching and indications through GPS systems to mobile apps that manage public transportation [7], and even to the most advanced systems of autonomous driving [8]. In this sense, the Internet of Vehicles (IoV) will bring great benefits, since each vehicle will be continuously connected with other vehicles, the infrastructure, the cloud, pedestrians and cyclists, as well as other road elements [9], allowing vehicles to detect and anticipate road hazards, thus avoiding possible traffic accidents. Efforts are being made towards this goal, although full connectivity is technologically complicated given the problems caused by the amount of simultaneous information, vehicle density, or the delay of emergency cooperative control messages, which hinder the reliability and scalability of wireless transmissions $[10,11]$. 
It has not been long since the term Smart City made its first appearance; it can be defined as territories with a high capacity for learning and innovation, which results from the creativity of their population, their institutions of knowledge creation, and their digital infrastructure for communication and knowledge management [12]. The idea of a Smart City is the fusion of some other, and older, urban policies, such as digital cities, green cities or smart mobility [13]. In this field, intelligent transport systems (ITS) have implied a rise in the development of new technological proposals applied to the world of transportation [14,15]. The possibility of using this technology to create vehicular networks particularly stands out, meaning the possibility of communication between vehicles and infrastructures in order to provide very diverse services [16].

To some extent, all countries in the world have made an effort to include this type of device as a way to solve road problems [17]. In particular, the United States, China and Germany are some of the countries that have incorporated smart traffic lights networks, automatic channeled tolls, integral management of highways and tunnels, and intelligent devices for the transportation of passengers, among other mechanisms [18].

However, does the population really perceive this phenomenon as an advance or an improvement in traffic? Do they perceive problems in having to provide personal data in the use and application of some of these systems? In this sense, there is variability depending on the integration of these devices. Therefore, countries that have incorporated sustainable urban mobility policies within the development and implementation of multiple technologies usually have a favorable opinion of these systems, since they perceive their potential benefits [19].

On the other hand, the situation in emerging countries is certainly different. In these places, the socioeconomic situation does not allow for the investment of many resources in these systems [20]. In this way, the lack of devices for the improvement of traffic and mobility, together with the low use of those available by the population, such as in the case of mobile apps, leads to a certain reticence or lack of trust towards the incorporation of new ITS systems [21,22].

During recent decades, the acceptance of technology by the population has been approached from different theoretical perspectives, with two of them standing out [23]. On the one hand, the Technology Acceptance Model (TAM), proposed by Davis (1989) [24], aims to explain human behavior related to the intention to perform a behavior as the primary determinant of the use of technologies. Perceived ease of use and perceived usefulness are the main determinants of technology use, exerting their influence through attitude towards use, which, in turn, influences the intention to use [25]. On the other hand, the Theory of Planned Behavior (TPB) by Schifter and Ajzen (1985) [26] suggests that the intention to behave could be, indeed, the best predictor of behavior, with attitude and subjective norm as antecedent factors. This theory adds an important element which is the perceived behavioral control factor, which refers to the individual's perceptions about the presence or absence of resources or opportunities necessary to develop the behavior in question [27].

Applying it to the area of traffic technology, the TAM and TPB models show the importance of a positive attitude and appreciation on the part of users towards electronic devices and ITS systems in order to increase the possibilities of use. Therefore, before implementing this technology in emerging countries, where its current penetration is minimal, it is advisable to evaluate the degree of knowledge and acceptance of these systems by their citizens.

\subsection{The Situation of Emerging Latin American Countries in the Road Traffic and Mobility Sector}

Latin American cities have severe congestion and road safety problems that are defined by the dynamics of transportation use. In the past, private vehicles were mainly cars, but in recent years motorcycles have increased exponentially as a common means of transport in countries such as Colombia, Venezuela, and Brazil, among others [28]. 
The factors that have triggered this situation are diverse. On the one hand, the low cost of acquisition and maintenance of motorcycles is key given the limited economic resources of most of the inhabitants of Latin American countries [29]. On the other hand, the importance of motorcycles for work performance is highlighted in the expansion of motorcycle cabs or "motoconchos". These two-wheeled vehicles are used for popular transportation in suburban areas and have become one of the most common ways of getting around in these countries [30].

In addition, the services offered by collective means of transport are very deficient. The reliability, accessibility, and fares of public transport do not meet the needs of citizens. This means that in cities such as Santo Domingo, in the Dominican Republic, the subway and OMSA buses (Metropolitan Office of Public Bus Services of the country) only transport $10 \%$ of the population that uses public transport [31]. One explanation for this is that these means of transportation are not capable of satisfying the demand required by the centers of passenger concentration [32]. For this reason, the bulk of collective transport trips are concentrated in public cars (private vehicles used for passenger transport), "guaguas" buses, and motorcycle cabs. All of them, in general, do not have established stops but pick up passengers at the points where they wait, causing traffic congestion [31]. In addition, the fleets are smaller in capacity and very old [33].

All these factors generate a situation of road insecurity and problems in traffic mobility that could be alleviated with an improvement in transport dynamics, accompanied by progressive incorporation of technologies, applications, and ITS systems to support traffic and travel management.

\subsection{Objectives}

Currently, the Dominican Republic displays issues related to accidents and mobility that affect traffic jams and the levels of pollution in the country [34]. This issue could, in part, be reduced through the importation of certain ITS systems. Therefore, the present research has as its objective clarifying the extent of the use of new technology in the field of transportation in the Dominican Republic, as well as the level of knowledge and approval of other systems and devices that could be implemented in the country during the next years. The National Institute of Transit and Land Transportation (INTRANT), created in 2017, has developed efforts and initiatives in terms of traffic management, planning, and education that have an impact on the perception of the situation of the country by its citizens. For this reason, the use and valuation of technology by Dominicans in the field of traffic in 2018 and 2019 will be analyzed, anticipating a significant increase in both elements, given the governmental efforts made during these years.

\section{Materials and Methods}

\subsection{Participants}

The sample included 1112 (in 2018) and 1272 (in 2019) citizens of the Dominican Republic. The sample distribution was proportional to the population, according to the ONE census (National Statistical Office), by age (older than 18), gender, habitat and province (Table 1). To obtain the necessary representativeness, the minimum sample size should be about $n=680$ individuals, if we assume a level of confidence of $99 \%$, a maximum margin of error of $5 \%(\alpha=0.05)$ and a beta $(\beta)$ of 0.20 , which allows for $80 \%$ power. The sampling characteristics were similar to those employed by other previous empirical research in the field of traffic and road safety using surveys as a self-report assessment instrument [35-37] (some key limitations typical for these designs are discussed at the end of this paper). Participants took part in the survey voluntarily and anonymously. All personal data were managed in compliance with the existing laws on data protection and following the ethical guidelines. 
Table 1. Sociodemographic characteristics.

\begin{tabular}{|c|c|c|c|c|c|}
\hline & & \multicolumn{2}{|c|}{2018} & \multicolumn{2}{|c|}{2019} \\
\hline & & $n$ & $\%$ & $n$ & $\%$ \\
\hline \multirow{3}{*}{ Sex } & Man & 585 & $52.6 \%$ & 636 & $50 \%$ \\
\hline & Woman & 527 & $47.4 \%$ & 636 & $50 \%$ \\
\hline & Total & 1112 & $100 \%$ & 1272 & $100 \%$ \\
\hline \multirow{6}{*}{ Age } & $18-24$ & 216 & $19.4 \%$ & 266 & $20.6 \%$ \\
\hline & $25-34$ & 288 & $25.9 \%$ & 317 & $24.7 \%$ \\
\hline & $35-49$ & 333 & $29.9 \%$ & 366 & $29.0 \%$ \\
\hline & $50-64$ & 183 & $16.5 \%$ & 221 & $17.5 \%$ \\
\hline & $>65$ & 92 & $8.3 \%$ & 102 & $8.1 \%$ \\
\hline & Total & 1112 & $100 \%$ & 1272 & $100 \%$ \\
\hline \multirow{5}{*}{ Marital status } & Single & 495 & $44.5 \%$ & 437 & $34.2 \%$ \\
\hline & Married/free union & 548 & 49.3 & 706 & $55.6 \%$ \\
\hline & Divorced/separated & 37 & $3.3 \%$ & 83 & $6.6 \%$ \\
\hline & Widow/widower & 32 & $2.9 \%$ & 46 & $3.7 \%$ \\
\hline & Total & 1112 & $100.0 \%$ & 1272 & $100 \%$ \\
\hline \multirow{5}{*}{ Job situation } & Unemployed & 238 & $21.4 \%$ & 458 & $41.6 \%$ \\
\hline & Retired & 30 & $2.7 \%$ & 41 & $3.7 \%$ \\
\hline & Full-time job & 215 & $19.3 \%$ & 213 & $19.3 \%$ \\
\hline & Part-time job & 581 & $52.2 \%$ & 390 & $35.4 \%$ \\
\hline & Total & 1112 & $100 \%$ & 1102 & $100 \%$ \\
\hline \multirow{3}{*}{ Do you usually drive? } & Yes & 402 & $36.2 \%$ & 476 & $37.3 \%$ \\
\hline & No & 710 & $63.8 \%$ & 796 & $62.7 \%$ \\
\hline & Total & 1112 & $100 \%$ & 1272 & $100 \%$ \\
\hline
\end{tabular}

\subsection{Design, Procedure and Instruments}

The data were gathered through the National Survey on Mobility of the Dominican Republic during the years 2018 and 2019 [38,39]. Some of the topics included in the questionnaire were public transportation, knowledge of institutions and traffic laws, private transportation, mobility by bike, mobility on foot, ITS systems, and measures, among which the variables considered in this research can be found.

The survey was carried out through in-person interviews. The data gathering process was performed using a CAPI system (computer assisted interviews), in recorded and geo-referenced tablets, so that the interview time, as well as recording mistakes, would be minimized.

In order to achieve the proposed objectives, the following variables were taken into account:

- On ITS systems, information was obtained through questions such as: "Do you know what ITS systems are? Do you know what Smart Cities are? Do you know what Smart Mobility is? Do you know what Contactless Cards are?". Each question had one option (yes/no) answer. The assessment of these systems was performed through a Likert scale ranging from 0 to 10. This same Likert scale was also used for the following questions: "To what extent do you consider that technology can be useful for the improvement of traffic? To what extent would you agree to provide your data for this purpose?". In addition to assessing the priority of different potential services, the question "In what field do you feel their incorporation should be prioritized?" was assessed through one option answer (highways, urban areas, interurban areas, and depends on the service).

- Regarding applications used for the trip, information was obtained with an open answer: "Do you use apps for your movements, or displacements?" with one option for an answer (yes/no); "Which ones?" with an open answer; “To what extent could 
apps foster the use of public transportation?" and "To what extent could they improve traffic and mobility in the country?", with a Likert scale from 0 to 10.

- Sociodemographic variables and driving data: sex, age group, habitat, do you usually drive?

\subsection{Data Processing}

For this study, descriptive analyses were carried out with the objective of describing and characterizing the level of knowledge of the ITS systems held by Dominican citizens. ANOVA and chi square tests were performed as well, in order to find out the evolution of the variables through time, between the administration of both surveys, as well as to establish possible statistical relations among the analyzed variables. Once the data were obtained, pertinent statistical analyses were carried out using ( $)$ IBM SPSS (Statistical Package for Social Sciences), version 26.0.

\subsection{Ethics}

Before performing the study, the Ethics Committee of Research in Social Science in Health of the University of Valencia was consulted, which confirmed the research's compliance with the general ethical standards and certified its accordance with the Declaration of Helsinki (IRB approval number: HE0001251019). Participants provided their consent before taking part in the research, after the staff had given them a thorough explanation of the research purpose and all the previous considerations.

\section{Results}

Dominicans, in general, have no knowledge of intelligent transportation (ITS). In the year 2018 , only $5 \%$ of them stated that they have some knowledge on the topic, while, in the following year, this percentage rose to $8.2 \%$. Despite this low general knowledge, the increase was significant (Table 2).

Table 2. Level of knowledge of intelligent transportation systems (ITS) systems.

\begin{tabular}{|c|c|c|c|c|c|c|c|c|}
\hline & & \multicolumn{2}{|c|}{2018} & \multicolumn{2}{|c|}{2019} & \multirow[b]{2}{*}{ Chi2 } & \multirow[b]{2}{*}{$p$} & \multirow[b]{2}{*}{ Phi } \\
\hline & & $\%$ & $n$ & $\%$ & $n$ & & & \\
\hline Do you know ITS systems? & $\begin{array}{l}\text { Yes } \\
\text { No }\end{array}$ & $\begin{array}{c}5.0 \% \\
95.0 \%\end{array}$ & $\begin{array}{c}56 \\
1056\end{array}$ & $\begin{array}{c}8.2 \% \\
91.8 \%\end{array}$ & $\begin{array}{c}103 \\
1157\end{array}$ & Chi2(1) $=9.304$ & 0.002 & -0.063 \\
\hline
\end{tabular}

Smart Cities (3\%) and smart mobility (4.7\%), assessed in the year 2018, presented lower indexes. On the other hand, the 2019 National Survey included questions related to Contactless Cards, where only $4.4 \%$ of the population knew what they were, $3.9 \%$ of which actually owned one. Their assessment of this system was $M \approx 9(S D=1.66)$ in a [0-10] scale.

After these first generic questions, the participants received an explanation about what these concepts were, so that they could answer the subsequent questions with enough information.

In this sense, Dominicans consider that technology would be quite useful for improving traffic and mobility in the country, having significantly improved their perception in 2019 compared with the previous year (Table 3). 
Table 3. Level of perception of the usefulness of technologies in the improvement of traffic.

\begin{tabular}{|c|c|c|c|c|c|c|c|c|}
\hline & \multicolumn{3}{|c|}{2018} & \multicolumn{3}{|c|}{2019} & \multirow[b]{2}{*}{ ANOVA } & \multirow[b]{2}{*}{$p$} \\
\hline & $X$ & $S D$ & $n$ & $X$ & $S D$ & $n$ & & \\
\hline $\begin{array}{c}\text { To what extent do you consider technology } \\
\text { useful for the improvement of traffic? }\end{array}$ & 7.34 & 2.46 & 1112 & 7.94 & 2.97 & 1272 & $F(1,2370)=28.872$ & $<0.001$ \\
\hline
\end{tabular}

In the National Survey on Mobility carried out in 2018, the level of acceptance showed by citizens towards a possible implantation of some ITS systems was analyzed in greater depth. The degree of agreement with their incorporation was relatively good $(M=6.68 ; S D=2.46)$, but very few people were willing to provide their data for this purpose $(M=3.32 ; S D=2.49)$. On the other hand, the field in which they believed their incorporation was the most urgent was in highways (52.5\%), followed by urban areas $(14.1 \%)$ and interurban areas $(13.9 \%)$, while $17.1 \%$ think it depends on the specific service. Figure 1 shows the services which were perceived as the most prioritized ones (in terms of ITS systems) by Dominican citizens.

\section{ITS systems' use priority}

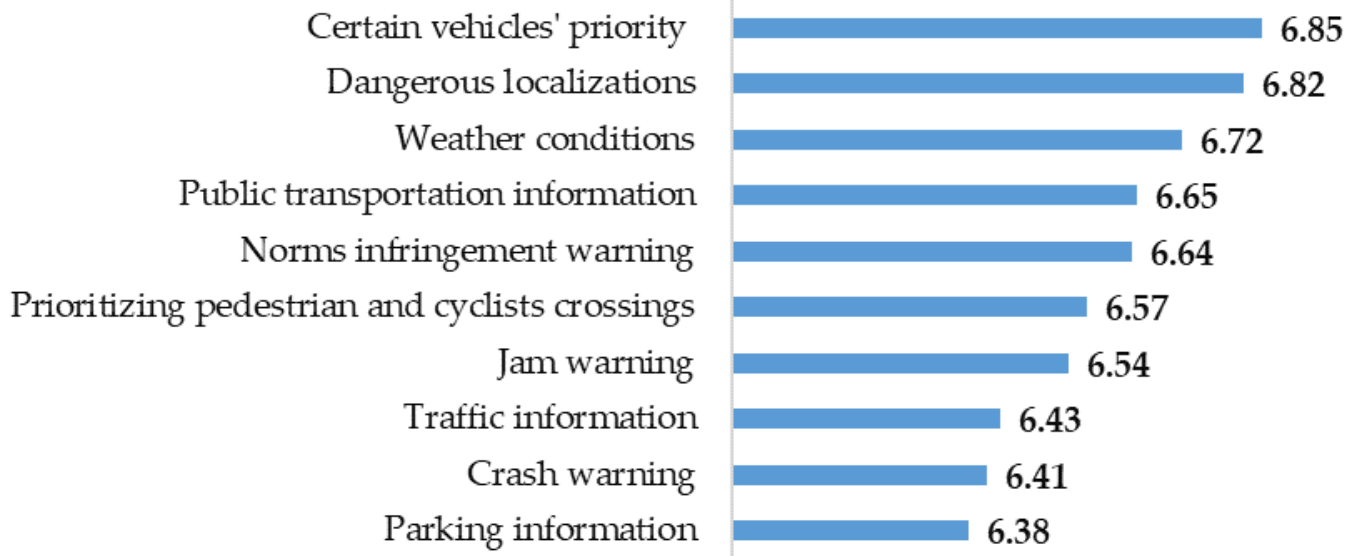

Figure 1. Priority of the use of intelligent transportation systems (ITS) according to Dominican citizens.

Regarding the application of these services for mobility, during both years their use was relatively scarce, even though there was a significant increase in 2019 in comparison with the previous year (Table 4). Figure 2 shows the most used apps, among which those related to navigation, maps and routes particularly stand out.

Table 4. Level of use of applications for mobility.

\begin{tabular}{|c|c|c|c|c|c|c|c|c|}
\hline & & \multicolumn{2}{|c|}{2018} & \multicolumn{2}{|c|}{2019} & \multirow[b]{2}{*}{ Chi2 } & \multirow[b]{2}{*}{$p$} & \multirow[b]{2}{*}{ Phi } \\
\hline & & $\%$ & $n$ & $\%$ & $n$ & & & \\
\hline $\begin{array}{l}\text { Do you use Apps for your } \\
\text { movements/displacements? }\end{array}$ & $\begin{array}{l}\text { Yes } \\
\text { No }\end{array}$ & $\begin{array}{l}10.9 \% \\
89.1 \%\end{array}$ & $\begin{array}{l}121 \\
991\end{array}$ & $\begin{array}{l}16.9 \% \\
83.1 \%\end{array}$ & $\begin{array}{c}213 \\
1047\end{array}$ & Chi2(1) = 17.715 & $<0.001$ & 0.086 \\
\hline
\end{tabular}




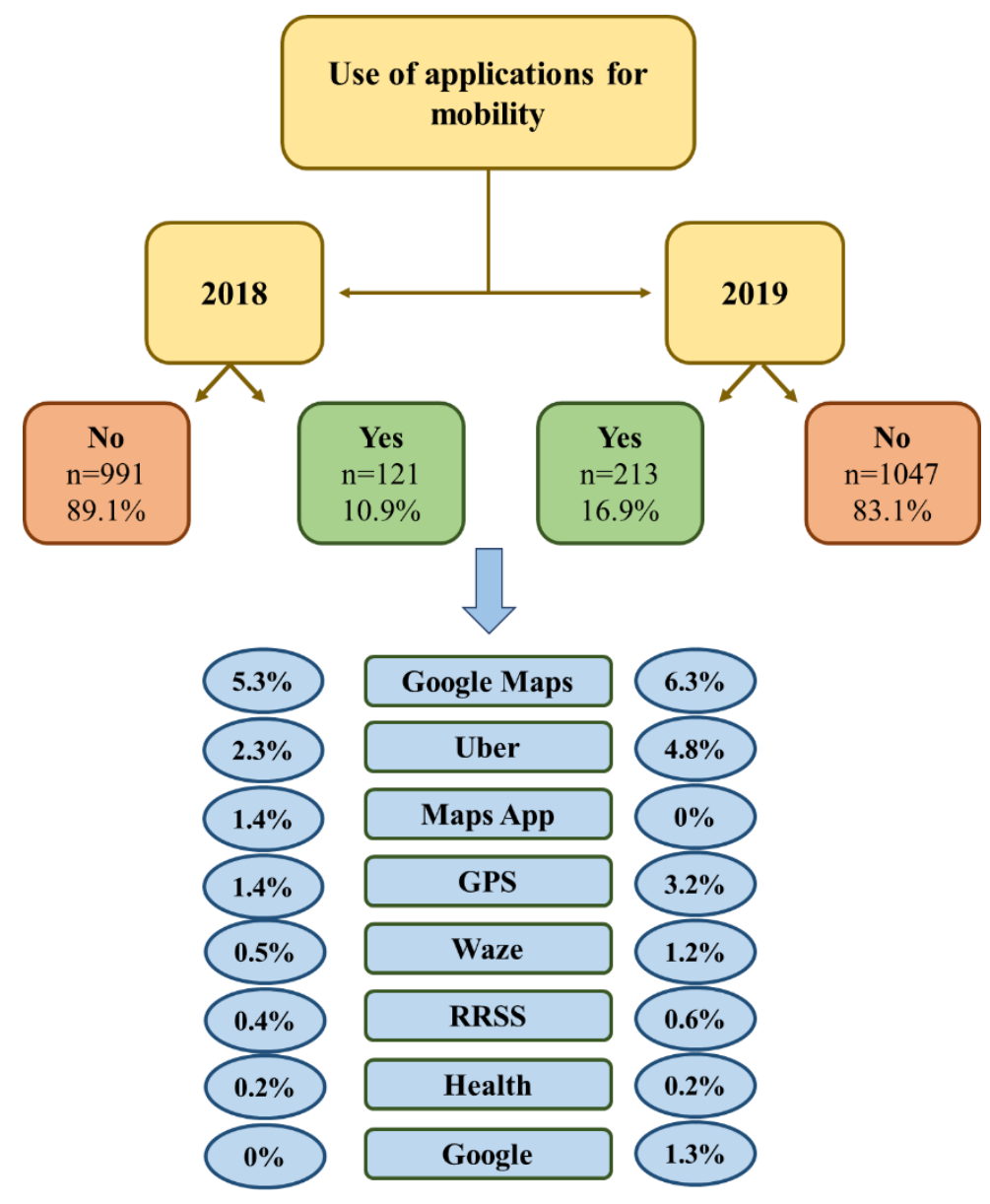

Figure 2. Applications used for displacements.

Moreover, generally speaking, Dominicans partially agree with the idea of apps fostering the use of public transportation and improving traffic and mobility in the country (Table 5).

Table 5. Level of perception of apps for the improvement of traffic elements.

\begin{tabular}{|c|c|c|c|c|c|c|c|c|}
\hline & \multicolumn{3}{|c|}{2018} & \multicolumn{3}{|c|}{2019} & \multirow[b]{2}{*}{ ANOVA } & \multirow[b]{2}{*}{$p$} \\
\hline & $X$ & $S D$ & $n$ & $\mathbf{X}$ & $S D$ & $n$ & & \\
\hline Fomentation of public transportation & 7.12 & 2.63 & 1112 & 7.54 & 3.03 & 1272 & $F(1,2370)=12.791$ & $<0.001$ \\
\hline Improvement of traffic and mobility & 7.24 & 2.66 & 1112 & 7.74 & 3.13 & 1272 & $\mathrm{~F}(1,2370)=17.015$ & $<0.001$ \\
\hline
\end{tabular}

\section{Discussion}

The importance of new technological devices for the improvement of mobility, road safety and sustainability of cities is clear [40]. Intelligent transport systems (ITS) represent a support mechanism for citizens and for public institutions in the attempt to alleviate issues such as traffic jams in urban and interurban public transportation; they also collaborate in the reduction in delays in journeys, they help to detect and prevent accidents, and they contribute to reducing acoustic pollution in urban areas and the consumption of non-renewable resources, as well as the generation of waste [41,42].

In this sense, the TAM and TPB theoretical models show the need for the target population of these devices and systems to have a good predisposition towards their use. Thus, in behavioral change, it is essential to take into account variables such as attitude towards the device, perceived usefulness, ease of use, or the individual's perceptions about the presence of the necessary resources to develop the behavior $[24,26]$. In this way, the 
intention to use the device will benefit if society starts from positive beliefs and a positive evaluation of the product.

This is evident in practice, if it is considered that citizens residing in places where the use of these systems is habitual usually present a certain knowledge and positive evaluation of them. Thus, $60 \%$ of inhabitants of urban zones think that an intelligent city is a synonym of sustainability and better services, and more than $30 \%$ of citizens are willing to pay more for certain cervices, if they are linked to some ITS system, because they understand that their quality would be more satisfactory [43]. Therefore, in the process of implementing ITS systems in the field of traffic in emerging countries, the first step is to make them known and explain their usefulness to the population. This is the best way to increase their levels of acceptance and involvement [44]. This will lead to a favorable and predisposed environment for these devices, which will generate a greater intention to use them [23].

In this sense, it is expected that the knowledge of concepts such as Smart Cities or ITS systems will be low in the Dominican Republic, since there is a huge digital gap in what concerns information and communication (TIC) technologies, in comparison with other countries. Digital gaps are an inescapable reality in the country, with social and economic consequences affecting social groups with fewer possibilities to access and use ICTs, mainly due to the existing Internet gap [45].

Even though there is no generalized inclusion of these technologies in emerging countries such as the Dominican Republic yet, the data of the present study show a positive tendency towards the use of the available technological services. During the past few years, Latin American countries have increased their technological development, even though they are still far from the levels of implementation seen in Western Europe or in North America [46].

Information technology is a key aspect in the understanding of Smart Cities, which, in the end, represent the connection between the Internet of Things (IoT), cloud computation and big data [47]. Therefore, they are systems and processes which require the gathering and processing of huge amounts of data [48].

In this sense, the present research also shows that there is a certain lack of trust regarding the need to provide personal data. This is a habitual feeling concerning technological devices and the Internet, especially in users who are just being introduced to these services and devices [49]. This phenomenon also occurs, to a lesser extent, in countries where information technology and the Internet are already inseparable from citizens, since they have already gone through a process of habituation [50].

Anyhow, having a certain level of trust in ITS systems is essential for their use [51]. Therefore, citizens must demand policies that protect their privacy [52]. In this sense, it has been found that the majority of the population would agree with governments regulating the activities of big technology companies, because they fear for their personal data [53]. Indeed, the more digital devices have been implemented in countries, the more there has been a need for developing specific laws to set limits and restrict the collection of citizens' personal data, in order to protect their fundamental right to privacy [54]. The Law on Cybersecurity of the Chinese Popular Republic [55] or the General Data Protection Regulation of the European Union [56] are just two examples of laws that have been globally implemented during the past few years [57]. Thus, this element should be taken into account in emerging countries aiming at implementing these types of technologies during the upcoming years.

On the other hand, despite the tendency to positively assess the usefulness of mobile apps to manage public transportation and mobility in the country, and the fact that there is an increase in their use, what is certain is that the use of apps is still scarce. What factors are influencing this phenomenon? To begin with, we must highlight the extent of the use of mobile devices in the country. It is true that the Dominican Republic, together with Colombia, is the Latin American country that has experienced the highest growth in the use of digital networks and internet during the past few years, despite their high economic cost [58]. The National Statistics Office highlighted that, in 2005, 44.3\% of Do- 
minicans had access to a cellphone, while ten years later this percentage increased up to $88.8 \%[59,60]$. Currently, it can be said that all Dominicans have access to the Internet from their cellphones, with young people especially standing out [61]. This circumstance is especially relevant for a possible implementation of ITS systems in the country, since apart from enhancing key issues of transport (e.g., efficiency, safety and sustainability), it also increases individuals' familiarity with similar devices, including all those related to information and communication technologies, or ICTs $[62,63]$ However, the mere increase in the degree of exposition to technologies could not be interpreted, in any case, as a reliable warranty of its acceptance $[63,64]$, suggesting that greater efforts are needed to transmit confidence in electronic devices, as well as to emphasize their relevance in improving mobility and reducing road accidents. Road safety education and communication campaigns will be key tools for this purpose [65].

Among those who use apps for their movements, the most used ones are related to maps and navigation. The National Institute of Traffic and Land Transportation (INTRANT) has proposed the creation of an app for the management of public transportation that could allow users to recharge their transport passes and to consult the vehicles' routes, among other functions [66]. However, its development and activation were finally paralyzed. It is, of course, complicated to combine all elements concerning public transportation in the Dominican Republic in one app, considering its particularities. The majority of displacements using collective transportation rely on buses and moto-taxis, which do not usually have established stops, instead picking up passengers wherever they wait [31]. Therefore, since there are no fixed routes, it is quite difficult to find an app that may help users to manage these modes.

Moreover, this transport dynamic represents a severe problem for the country's mobility, since it leads to huge jams in urban zones, with all the associated individual and social issues they involve [32]. The metro and OMSA buses, which are only available in urban zones such as Santo Domingo, do present a better structure concerning stops and routes, in addition to being better evaluated by users [33]. However, they are much less used, due to economic and inter-connection reasons of transport modes [31].

In conclusion, Dominican society will benefit from a change in this transportation dynamic, which could be connected to and empowered by the use of ITS systems and applications in traffic management, mobility and public transportation. There are several elements that indicate this: (1) the current problems related to traffic mobility in the Dominican Republic; (2) the positive opinion of the citizens about the help that technology and ITS systems could bring to this area; and (3) the improvement that these systems have brought in other countries.

\section{Limitations and Future Research}

Although the study design and its representativeness were founded on a careful study of the population settings, and the sample was proportional to the ONE census in terms of sex, age, population, and province of residence (counting with a sample size much larger than the minimum required), this study is not exempt from potential bias and shortcomings affecting its outcomes. Firstly, it is worth mentioning the possibility of having sampling bias, i.e., affecting the selection process and making some individuals systematically more likely to be invited to partake than others. For instance, certain population segments less prone to be highly familiar with technologies could be underrepresented (e.g., among older adults, their degrees of knowledge or interaction with ITCs were not considered as selection criteria), meaning that their group outcomes could be biased, or some segments undercovered. Therefore, generalizing the study data to the general public could be done only in consideration of these potential shortcomings $[67,68]$. In addition, we performed inperson interviews, and even though respondents were carefully informed beforehand about the rigorously anonymous character of the information they provided, some respondents might have been influenced by common method variance (e.g., participants potentially 
overestimating their acceptance of technology because they perceive it as being socially desirable), that are frequent in this type of setting [69].

Additionally, although it could be seen as an extensive term at first glance, the time difference between the two implementations of the survey was only one year. This was a period of many changes in the traffic and mobility sector in the Dominican Republic, and in fact, the present study demonstrates a positive evolution of the citizens in their knowledge and evaluation of the elements analyzed. However, future research is needed to analyze in depth the changes that may occur over the years in this field.

One aspect that could enrich the present research is to obtain the views of government officials, of different transportation agencies and private sectors related to transit, mobility, and road safety in order to understand their opinion about future expectations, possible technological obstacles, and financing problems in their countries, regarding the implementation of intelligent transportation systems.

\section{Conclusions}

More and more countries are investing in the development and implementation of intelligent transport systems (ITS), because they acknowledge their positive consequences on road safety, mobility and sustainability in cities [40]. Within each country's specific dynamics of transportation, information technologies can also help to improve their management. However, governmental authorities should take into account the fact that, among these improvements, they should include policies protecting their citizens' privacy and reducing the initial lack of trust that these may have.

The present study offers a first-hand approximation with regard to the general state in the Dominican Republic of the knowledge and acceptance of ITS systems and trafficmanagement applications. It is important to analyze each country's situation, and its citizens' opinions, in order to optimize the available resources, so that they can be truly helpful to the population's transport habits.

Author Contributions: For this study, F.A. and M.F. conceived and designed the research, and performed the data collection; S.A.U. and M.F. analyzed the data; C.E. and S.A.U. contributed with reagents/materials/analysis tools; M.F. and S.A.U. wrote and revised the paper. All authors have read and agreed to the published version of the manuscript.

Funding: This study was funded by the National Institute of Transit and Land Transportation (INTRANT) and its Permanent Observatory in Road Safety (OPSEVI; public agency of the Dominican Republic)-Grant number: 20170475. And this work was supported by the research grant ACIF/2020/035 (MF) from "Generalitat Valenciana". Funding entities did not contribute to the study design or data collection, analysis and interpretation or writing of the manuscript.

Data Availability Statement: The data will be available upon reasonable request to the corresponding author.

Acknowledgments: The authors wish to thank to Mayte Duce for the revisions, and to Runa Falzolgher and Arash Javadinejad for the professional edition of the final version of the manuscript.

Conflicts of Interest: The authors declare no conflict of interest.

\section{References}

1. Quintero, J.R.; Prieto, L.F. Sistemas Inteligentes de Transporte y Nuevas Tecnologías en el Control y Administración del Transporte. 2015. Available online: https:/ / repository.upb.edu.co/handle/20.500.11912/7281 (accessed on 3 April 2021).

2. Solano, S.E.; Casado, P.P.; Ureba, S.F. Smart Cities and Sustainable Development. A Case Study. In Sustainable Smart Cities; Springer: Berlin/Heidelberg, Germany, 2017; pp. 65-67. [CrossRef]

3. Mans, D.; Jonkers, E.; Giannelos, I.; Palanciuc, D. Scaling up Methodology for CO2 Emissions of ICT Applications in Traffic and transport in Europe. In Proceedings of the Ninth ITS European Congress, Dublin, Ireland, 20-23 October 2013; pp. 4-7.

4. Hashem, I.A.T.; Chang, V.; Anuar, N.B.; Adewole, K.; Yaqoob, I.; Gani, A.; Ahmed, E.; Chiroma, H. The role of big data in smart city. Int. J. Inform. Manag. 2016, 36, 748-758. [CrossRef] 
5. Sánchez, J.A.S. Redes Vehiculares Aplicadas a la Movilidad Inteligente y Sostenibilidad Ambiental en Entornos de Ciudades Inteligentes. Universidad de Oviedo, 2017. Available online: https://dialnet.unirioja.es/servlet/dctes?codigo=207357 (accessed on 6 April 2021).

6. Steenbruggen, J.; Nijkamp, P.; van der Vlist, M. Urban traffic incident management in a digital society: An actor-network approach in information technology use in urban Europe. Technol. Forecast. Soc. 2014, 89, 245-261. [CrossRef]

7. Cabannes, T.; Vincentelli, M.A.S.; Sundt, A.; Signargout, H.; Porter, E.; Fighiera, V.; Ugirumurera, J.; Bayen, A.M. The Impact of GPS-Enabled Shortest Path Routing on Mobility: A Game Theoretic Approach. In Proceedings of the Transportation Research Board 97th Annual Meeting, Washington, DC, USA, 6-7 March 2018; pp. 7-11.

8. Nguyen, Q.-H.; Morold, M.; David, K.; Dressler, F. Car-to-Pedestrian communication with MEC-support for adaptive safety of Vulnerable Road Users. Comput. Commun. 2020, 150, 83-93. [CrossRef]

9. Zhou, H.; Xu, W.; Chen, J.; Wang, W. Evolutionary V2X technologies toward the internet of vehicles: Challenges and opportunities. Proc. IEEE 2020, 108, 308-323. [CrossRef]

10. Ni, Y.; Cai, L.; He, J.; Vinel, A.; Li, Y.; Mosavat-Jahromi, H.; Pan, J. Toward reliable and scalable internet of vehicles: Performance analysis and resource management. Proc. IEEE 2019, 108, 324-340. [CrossRef]

11. Ni, Y.; He, J.; Cai, L.; Bo, Y. Data uploading in hybrid V2V/V2I vehicular networks: Modeling and cooperative strategy. IEEE Trans. Veh. Technol. 2018, 67, 4602-4614. [CrossRef]

12. Komninos, N. The Architecture of Intelligent Clities: Integrating Human, Collective and Artificial Intelligence to Enhance Knowledge and Innovation. In Proceedings of the 2006 2nd IET International Conference on Intelligent Environments-IE 06, Athens, Greece, 5-6 July 2006; pp. 13-20.

13. Benevolo, C.; Dameri, R.P.; D’auria, B. Smart mobility in smart city. In Empowering Organizations; Springer: Berlin/Heidelberg, Germany, 2016; pp. 13-28. [CrossRef]

14. Festag, A. Cooperative intelligent transport systems standards in Europe. IEEE Commun. Mag. 2014, 52, 166-172. [CrossRef]

15. Djahel, S.; Doolan, R.; Muntean, G.-M.; Murphy, J. A communications-oriented perspective on traffic management systems for smart cities: Challenges and innovative approaches. IEEE Commun. Surv. Tut. 2014, 17, 125-151. [CrossRef]

16. Sjoberg, K.; Andres, P.; Buburuzan, T.; Brakemeier, A. Cooperative intelligent transport systems in Europe: Current deployment status and outlook. IEEE Veh. Techol. Mag. 2017, 12, 89-97. [CrossRef]

17. Xiong, Z.; Sheng, H.; Rong, W.; Cooper, D.E. Intelligent transportation systems for smart cities: A progress review. Sci. China Inform. Sci. 2012, 55, 2908-2914. [CrossRef]

18. Chen, B.; Sun, D.; Zhou, J.; Wong, W.; Ding, Z. A future intelligent traffic system with mixed autonomous vehicles and human-driven vehicles. Inform. Sci. 2020, 529, 59-72. [CrossRef]

19. Penmetsa, P.; Adanu, E.K.; Wood, D.; Wang, T.; Jones, S.L. Perceptions and expectations of autonomous vehicles-A snapshot of vulnerable road user opinion. Technol. Forecast. Soc. 2019, 143, 9-13. [CrossRef]

20. Zhang, R.; Ishikawa, A.; Wang, W.; Striner, B.; Tonguz, O.K. Using reinforcement learning with partial vehicle detection for intelligent traffic signal control. IEEE Trans. Intell. Transp. 2020. [CrossRef]

21. Gordo, J.M.; Malvaso, A.; Mazzarella, C.; Salvidio, A.; Sangineto, C. Accidentes Producidos por Vehículos Autónomos; Universidad Tecnológica Nacional: Buenos Aires, Argentina, 2019.

22. Meza, B.; Bismarck, E. Sistema Informático de Gestión Vehicular para la Empresa Municipal de Transporte, Tránsito, Seguridad Vial y Terminales Terrestres Santo Domingo EPMT-SD. 2017. Available online: http://dspace.uniandes.edu.ec/handle/12345678 9/6299 (accessed on 13 April 2021).

23. Tavera, J.F.; Londoño, B.E. Factores Determinantes de la Aceptación Tecnológica del E-commerce en Paises Emergentes. Sci. Estrateg. 2014, 22, 101-119, ISSN: 1794-8347. Available online: https:/ / www.redalyc.org/articulo.oa?id=151332653007 (accessed on 9 April 2021).

24. Davis, F.D. Perceived usefulness, perceived ease of use, and user acceptance of information technologies. MIS Quart. 1989, 13, 21. [CrossRef]

25. King, W.R.; He, J. A meta-analysis of the technology acceptance model. Inform. Manag. 2006, 43, 740-755. [CrossRef]

26. Schifter, D.E.; Ajzen, I. Intention, perceived control, and weight loss: An application of the theory of planned behavior. J. Pers. Soc. Psychol. 1985, 49, 843. [CrossRef]

27. Rao, S.; Troshani, I. A conceptual framework and propositions for the acceptance of mobile services. J. Theor. Appl. Electr. Commer. Res. 2007, 2, 61-73. [CrossRef]

28. Rodríguez, D.A.; Santana, M.; Pardo, C.F. La Motocicleta en América Latina: Caracterización de su Uso e Impactos en la Movilidad en Cinco Ciudades de la Región; CAF: Washington, DC, USA, 2015.

29. Hernández, D. Transporte público, bienestar y desigualdad: Cobertura y capacidad de pago en la ciudad de Montevideo. Rev. CEPAL 2017, 122, 165-185. [CrossRef]

30. Hernández, B.B.; Osorio, P.F.C. El servicio de mototaxis: Una fuente alternativa de trabajo en Puebla. DÍKÊ. Rev. Investig. Derecho Criminol. Consult. Jurídic. 2017, 8. [CrossRef]

31. González, P.D. Propuesta para la Mejora del Transporte Público en el Distrito Nacional. Santo Domingo. 2015. Available online: https:/ / repositorio.upct.es/handle/10317/5101 (accessed on 5 April 2021).

32. Montañez, M.R. Un nuevo modelo de transporte para el gran Santo Domingo. Cienc. Soc. 2016, 41, 337-359. Available online: https:/ / www.redalyc.org/pdf/870/87046120005.pdf (accessed on 3 April 2021). [CrossRef] 
33. Santana, E.A.; Marte, J.C. Propuesta Estratégica para la Mejora en la Calidad del Servicio de Transporte Público: Caso Transporte Expreso Tarea, Ruta Santo Domingo-Bonao. República Dominicana, 2017. Available online: http://investigare.pucmm.edu.do: 8080/xmlui/handle/20.500.12060/1861 (accessed on 7 April 2021).

34. Galindo, L.M.; Cruz-Rodríguez, A.; Dishmey, Y.; Francos, M.; López, J.C.; Alatorre, J.E.; van der Borght, R. Escenarios Para un Desarrollo Sostenible en la República Dominicana: Un Modelo Econométrico Estructural de Emisiones de Dióxido de Carbono. 2020. Available online: https:/ / repositorio.cepal.org/handle/11362/46019 (accessed on 15 April 2021).

35. Sanders, R.L. Perceived traffic risk for cyclists: The impact of near miss and collision experiences. Accid. Anal. Prev. 2015, 75, 26-34. [CrossRef] [PubMed]

36. Chen, G.X.; Sieber, W.K.; Lincoln, J.E.; Birdsey, J.; Hitchcock, E.M.; Nakata, A.; Robinson, C.; Collins, J.W.; Sweeney, M.H. NIOSH national survey of long-haul truck drivers: Injury and safety. Accident. Anal. Prev. 2015, 85, 66-72. [CrossRef]

37. Struckman-Johnson, C.; Gaster, S.; Struckman-Johnson, D.; Johnson, M.; May-Shinagle, G. Gender differences in psychosocial predictors of texting while driving. Accid. Anal. Prev. 2015, 74, 218-228. [CrossRef]

38. INTRANT. National Mobility Survey of the Dominican Republic, Results REPORT 2018; Instituto Nacional de Tránsito y Transporte Terrestre: Santo Domingo, Dominican Republic, 2019.

39. INTRANT. National Mobility Survey of the Dominican Republic, Results REPORT 2019; Instituto Nacional de Tránsito y Transporte Terrestre: Santo Domingo, Dominican Republic, 2020.

40. Singh, S.; Sharma, P.K.; Yoon, B.; Shojafar, M.; Cho, G.H.; Ra, I.-H. Convergence of blockchain and artificial intelligence in IoT network for the sustainable smart city. Sustain. Cities Soc. 2020, 63, 102364. [CrossRef]

41. Pons, J.M.S.; Reynés, M.R.M.; de la Terra, D.C. Los Sistemas Inteligentes de Transporte y sus Efectos en la Movilidad Urbana e Interurbana; Geo Crítica/Scripta Nova. Revista Electrónica de Geografía y Ciencias Sociales; Universidad de Barcelona: Barcelona, Spain, 2004; Volume 1, p. 170. Available online: http:// www.ub.edu/geocrit/sn/sn-170-60.htm (accessed on 15 April 2021).

42. Al Nuaimi, E.; Al Neyadi, H.; Mohamed, N.; Al-Jaroodi, J. Applications of big data to smart cities. J. Internet Serv. App. 2015, 6, 1-15. [CrossRef]

43. Capgemini Research Institute. Street Smart: Putting the Citizen at the Center o a Smart City Iniciatives; Capgemini Research Institute: Paris, France, 2020.

44. Hougham, R.J.; Nutter, M.; Graham, C. Bridging natural and digital domains: Attitudes, confidence, and interest in using technology to learn outdoors. J. Exp. Educ. 2018, 41, 154-169. [CrossRef]

45. Observatory of Social Policies and Development. Brecha Digital: Situación Actual y los Centros Tecnológicos Comunitarios (CTC) como Política de Mitigación. Boletín del Obs. de Políticas Soc. Para la Inclusión Soc. y Económica 2017. Available online: https:/ / www.researchgate.net/profile/Jose-Tavares-24/publication/323747586_BRECHA_DIGITAL_situacion_atual_y_ los_Centros_Tecnologicos_Comunitarios_CTC_como_politica_de_mitigacion/links/5aa8af97a6fdcc1b59c64511/BRECHADIGITAL-situacion-actual-y-los-Centros-Tecnologicos-Comunitarios-CTC-como-politica-de-mitigacion.pdf (accessed on 12 April 2021).

46. Agudelo, M.; Chomali, E.; Suniaga, J.S.; Núñez, G.; Jordán, V.; Rojas, F.; Negrete, J.; Bravo, J.; Bertolini, P.; Katz, R. Las Oportunidades de la Digitalización en América Latina Frente al COVID-19; CAF: Washington, DC, USA, 2020; Available online: https:/ / scioteca.caf.com/handle/123456789/1541 (accessed on 14 April 2021).

47. Edwards, L. Privacy, security and data protection in smart cities: A critical EU law perspective. Eur. Data Prot. Law Rev. 2016, 2, 28. [CrossRef]

48. Vandercruysse, L.; Buts, C.; Dooms, M. A typology of Smart City services: The case of Data Protection Impact Assessment. Cities 2020, 104, 102731. [CrossRef]

49. Chen, D.; Zhao, H. Data security and privacy protection issues in cloud computing. In Proceedings of the 2012 International Conference on Computer Science and Electronics Engineering, Hangzhou, China, 23-25 March 2012; pp. 647-651. [CrossRef]

50. Kim, B. The diffusion of mobile data services and applications: Exploring the role of habit and its antecedents. Telecommun. Policy 2012, 36, 69-81. [CrossRef]

51. Seckler, M.; Heinz, S.; Forde, S.; Tuch, A.N.; Opwis, K. Trust and distrust on the web: User experiences and website characteristics. Comput. Hum. Behav. 2015, 45, 39-50. [CrossRef]

52. Matzutt, R.; Müllmann, D.; Zeissig, E.-M.; Horst, C.; Kasugai, K.; Lidynia, S.; Wieninger, S.; Ziegeldorf, J.H.; Gudergan, G.; Wehrle, K. myneData: Towards a trusted and user-controlled ecosystem for sharing personal data. Informatik 2017. [CrossRef]

53. Amnesty International New Poll Reveals 7 in 10 People Want Goverments to Regulate Big Tech over Personal Data Fears. 2017. Available online: https://www.amnesty.org/en/latest/news/2019/12/big-tech-privacy-poll-shows-people-worried/ (accessed on 14 April 2021).

54. Blackburn, C. New technology, personal data protection and implications 'for financial services regulation'. JASSA 2015, 59-65. [CrossRef]

55. Morán, D.R. Ciberseguridad en China. Bie3 Boletín IEEE 2017, 5, 8-15.

56. Regulation (EU) 2016/679 of the European Parliament and of the Council of 27 April 2016 on the Protection of Natural Persons with Regard to the Processing of Personal Data and on the Free Movement of Such Data, and Repealing Directive 95/46/EC (General Data Protection Regulation). Available online: https://op.europa.eu/es/publication-detail/-/publication/3e485e15-11 bd-11e6-ba9a-01aa75ed71a1/language-en (accessed on 13 April 2021). 
57. Piper, D. Data protection laws of the world. DLA Piper 2016. Available online: https://www.dlapiperdataprotection.com/ (accessed on 11 April 2021).

58. Reyes, P. Internet Crece en RD a Pesar de su Alto Costo; Listín Diario: Santo Domingo, Dominican Republic, 2015.

59. ONE. Boletín Panorama Estadístico 56 Evolución del Uso de Internet de la Poblaciçon de 12 Años y Más Edad en República Dominicana. Enhogar 2005-2011 Mayo 2013; Oficina Nacional de Estadística: Santo Domingo, Dominican Republic, 2013.

60. Bretón, A.B. Diagnóstico de la Percepción de los Estudiantes Universitarios de Comunicación de República Dominicana Sobre las Plataformas Online y el uso del Lenguaje Transmedia. Ph.D. Thesis, Universitat Autònoma de Barcelona, Catalonia, Spain, 2020.

61. ONE. Encuesta Nacional de Actividad Económica: Información y Comunicaciones 2018; Oficina Nacional de Estadística: Santo Domingo, Dominican Republic, 2019.

62. Anderson, S.E.; Putman, R.S. Special education teachers' experience, confidence, beliefs, and knowledge about integrating technology. J. Spec. Educ. Technol. 2020, 35, 37-50. [CrossRef]

63. Montoro, L.; Useche, S.A.; Alonso, F.; Lijarcio, I.; Bosó-Seguí, P.; Martí-Belda, A. Perceived safety and attributed value as predictors of the intention to use autonomous vehicles: A national study with Spanish drivers. Saf. Sci. 2019, 120, 865-876. [CrossRef]

64. Lijarcio, I.; Useche, S.A.; Llamazares, J.; Montoro, L. Availability, Demand, Perceived Constraints and Disuse of ADAS Technologies in Spain: Findings from a National Study. IEEE Access 2019, 7, 129862-129873. [CrossRef]

65. Bonnet, E.; Lechat, L.; Ridde, V. What interventions are required to reduce road traffic injuries in Africa? A scoping review of the literature. PLoS ONE 2018, 13, e0208195. [CrossRef]

66. INTRANT. APP Sistema Integrado de Transporte Público del Gran Santo Domingo; Instituto Nacional de Tránsito y Transporte Terrestre: Santo Domingo, Dominican Republic, 2019.

67. Kelfve, S.; Thorslund, M.; Lennartsson, C. Sampling and non-response bias on health-outcomes in surveys of the oldest old. Eur. J. Ageing 2013, 10, 237-245. [CrossRef] [PubMed]

68. Useche, S.A.; Hezaveh, A.M.; Llamazares, F.J.; Cherry, C. Not gendered ... but different from each other? A structural equation model for explaining risky road behaviors of female and male pedestrians. Accid. Anal. Prev. 2021, 150, 105942. [CrossRef] [PubMed]

69. Jakobsen, M.; Jensen, R. Common Method Bias in Public Management Studies. Int. Public Manag. J. 2015, 18, 3-30. [CrossRef] 